\title{
Student Views on Playing Classical Music in the Background and Its Effects on Anatomy Practice Lessons
}

\section{Arka Planda Klasik Müzik Çalınmasının Anatomi Uygulama Derslerine Etkisi Üzerine Öğrenci Görüşleri}

\section{Erengül Boduç}

Kafkas University Faculty of Medicine, Department of Anatomy, Kars, Turkey

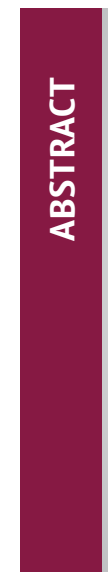

Background: The aim of this study is to reduce the fear and anxiety towards the cadaver in the anatomy practice lesson with the effect of classical music playing in the background.

Materials and Methods: One hundred fity seven students participated in the study. The questions asked were created with a 5-point Likert scale and the students answered the questions via mail. Answers were analyzed on the system and then statistically calculated.

Results: According to the statistics of the chi-square test of first and second grade answers, there was a significant difference only in the first $(p=0.017)$ and fourth $(p=0.015)$ questions $(p<0.05)$. Participation in the ninth, tenth and eleventh questions was quite high both in the first and second grades.

Conclusion: There are very few studies in the literature with the effect of classical music playing in the light background in the anatomy laboratory. It is important to include student responses in this study in the literature, so it is thought that the effect of classical music in the anatomy laboratory will reduce the stress and fear arising from the cadaver.

Keywords: Anatomy education, background music, five likert scale

Amaç: Bu çalışmanın amacı, arka planda klasik müzik çalmanın etkisi ile anatomi uygulama dersinde kadavralara yönelik korku ve kaygıyı azaltmaktır.

Gereç ve Yöntemler: Araştırmaya 157 öğrenci katıldı. Sorulan sorular 5’li Likert testi ile oluşturuldu ve öğrenciler soruları mail yoluyla cevapladılar. Cevaplar sistem üzerinde analiz edildikten sonra istatistiksel hesaplamalar yapıldı.

Bulgular: Birinci ve ikinci sınıf cevaplarının ki-kare testi istatistiğine göre, sadece birinci $(p=0,017)$ ve dördüncü $(p=0,015)$ sorularda anlamlı fark vardı $(p<0,05)$. Dokuzuncu, onuncu ve on birinci sorulara katılım hem birinci hem de ikinci sınıflarda oldukça fazlaydı.

Sonuç: Anatomi laboratuvarında klasik müzik çalmanın hafif arka planda etkisi ile literatürde çok az çalışma vardır. Bu çalışmada öğrenci yanıtlarının literatüre dahil edilmesi önemlidir, bu nedenle klasik müziğin anatomi laboratuvarındaki etkisinin kadavradan kaynaklanan stres ve korkuyu azaltacağı düşünülmektedir.

Anahtar Kelimeler: Anatomi eğitimi, arka plan müziği, beşli likert test

\section{Introduction}

Cadaver has been an important teaching tool in anatomy education for years and still continues (1). Although 3D digital software has tried to replace cadavers in recent years, its success in raising physicians has been lacking in replacing cadaveric education $(2,3,4)$. Moreover, the cadaver is actually the first patient of the students (5).

Cadaver education is actually laborious, it requires knowledge and effort $(6,7)$. Besides being beneficial, this training has some

Address for Correspondence: Erengül Boduç, Kafkas University Faculty of Medicine, Department of Anatomy, Kars, Turkey Phone: +90 5307849586 E-mail: erenboduc@gmail.com ORCID ID: orcid.org/0000-0001-8872-1993

Received: 08.12.2020 Accepted: 16.12.2020 
disadvantages as well $(7,8)$. The anatomy laboratory should be suitable for cadaver education. Cadaver tanks or pools should be stainless and attention should be paid to the toxic effects of the solutions that provide cadaver protection (9). Another negative disadvantage is the feeling of anxiety caused by seeing a cadaver (10).

Unfortunately, the cold and morgue appearance of the anatomy laboratory creates an emotional sense of anxiety in the instructors and students. Especially touching the cadaver to dissect it, spending time with it and the silence of the environment can sometimes negatively affect a person in this environment. Getting used to a dead body and a sense of death in students who have just taken the anatomy lesson can stress students at first. The same situation may be similar for instructors and postgraduate students $(10,11,12)$.

One of the recommended methods to reduce anxiety and stress caused by cadavers is education with music. When the studies on this subject are examined, it is observed that education with music is very beneficial in overcoming cadaver anxiety (10). In this study, students' opinions were taken for the adaptation of the classical music played in the light background to overcome the cadaver fear and to adopt the cadaver in the sense of anxiety faced by medical students in the anatomy laboratory. It is thought that the study will benefit cadaveric anatomy education.

\section{Material and Methods}

This study was approved by the Ethics Committee of Medicine Faculty of Kafkas University (approval number: 2020/06/ decision 11). The study was carried out on the first and second year medical students of Kafkas University Medicine Faculty in the 2019-2020 academic year. The data collection forms used in the study were prepared on the web and sent to the students by e-mail. 157 students (87 from first class, 70 from second class) answered the questions in the data collection form. Data collection questions were prepared with a five-point Likert scale (totally agree, agree, undecided, disagree, totally disagree) $(13,14)$. The answers given by the students were automatically analyzed through the web system and the results were obtained through the software. The answer options given were calculated automatically on the system with the calculation of frequency and percentage.

\section{Statistical Analysis}

The first and second years were compared according to the answers given by the students. Statistical analysis was carried out using SPSS 22.0 version software program for Windows. Descriptive statistics for categorical variables were expressed as frequency and percentage values. A chi-square test was used in the analysis of categorical data. The results were evaluated at a $95 \%$ confidence interval, and a $p$-value of $<0.05$ was considered significant.

The study was approved by the Ethics Committee of Kafkas University (approval number: 2020/06/ decision 11). The study was performed following the aid of the ethical standards down in the 1964 Declaration of Helsinki and its later amendments.

\section{Results}

The first and second years were compared according to the answers given by the students. Participation rate of first graders to the first question opinion was higher than that of second graders ( $43.7 \%$ agree, 24.2 totally agree, $p=0.017$ ). On the other hand, the number of undecided participants was almost equal. Participation to the second question opinion was high in the first year, while the rate of undecided people was higher in the second year (36.8\% agree, $27.3 \%$ undecided, $p=0.057$ ). Participation to the third question opinion was high in the first year, while the rate of those who did not agree with the third question was higher in the second year $(41.4 \%$ agree, $30.3 \%$ disagree, $p=0.032$ ). The numbers of first and second year students who absolutely disagreed with the fourth question were almost the same (37.9\% disagree, $34.4 \%$ disagree, $p=0.015)$. Participation in the opinion of the fifth question was high in the first grade, while the rate of undecided ones was high in the second grade $36.8 \%$ agree, $27.3 \%$ undecided, $p=0.244$ ). The numbers of participants who participated in the sixth question opinion in the first and second grades and did not agree were almost equal to each other (23.7\% agree, 24.2 agree; $23.6 \%$ disagree, $24.2 \%$ disagree; $p=0.961$ ). The numbers of those who totally agreed and agreed with the seventh question opinion in the first year were equal (36.8\%). In the second year, the number of participants was not very high; the numbers of those who disagreed and who were undecided were equal (15.4\% undecided-disagree). The $p$-value in the comparative statistics of the two classes was 0.090 . Participation to the eighth question opinion was quite high both in the first and second grades $(51.7 \%-42.4 \%$ agree, $p=0.558)$. Participation in the ninth, tenth and eleventh questions was quite high both in the first and second grades. The frequency percentages for these questions are given in Table 1 and Table 2. According to the statistics of the chi-square test of first and second grade answers, there was a significant difference only in the first and fourth questions $(p<0.05)$ (Table 3 ).

\section{Discussion}

The main tool of the anatomy laboratory has been the cadaver (15). However, cadaver education has some disadvantages $(7,8)$. One of them is the fear and anxiety created by the cadaver (10). The cold and morgue air of anatomy laboratories further increases the feeling of intense stress in meeting a dead body. It takes quite a bit of time to get used to this situation, such as 


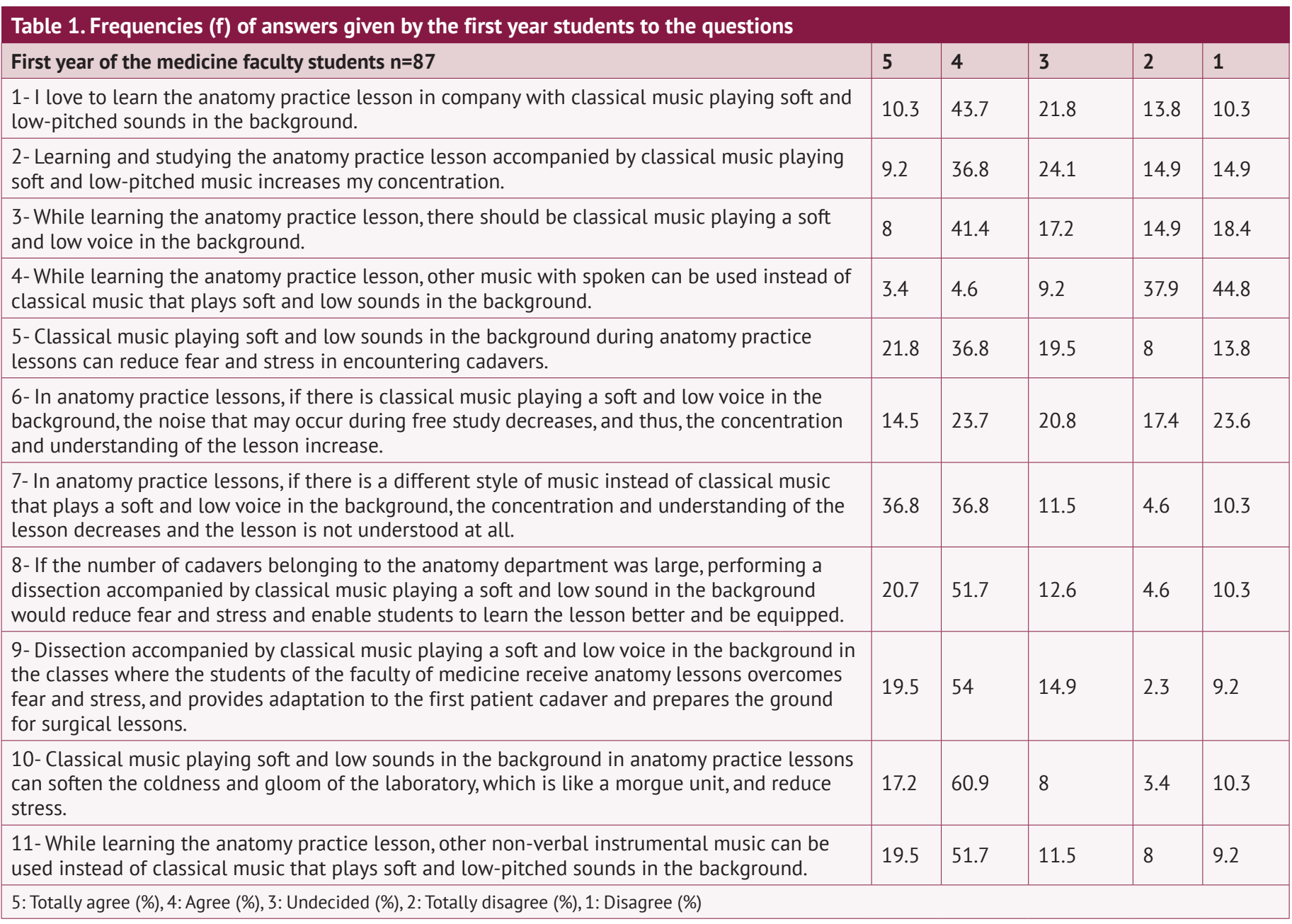

dissection, education or research, and sometimes these stress conditions cannot be adapted. In the studies conducted, it has been observed that playing soft background music in the anatomy laboratory reduces the fear and anxiety conditions arising from the cadaver. In addition, it has been observed that the concentration-increasing weft of the music increases the efficiency of scientific studies by providing easier orientation to the dissection $(10,11,12)$.

In this study, the perspective of first-year and second-year students to anatomy education with classical music playing in the light background is quite positive. When the questions are examined, it can be said that the first graders like to do the anatomy practice lesson with soft music in the background and this has a positive effect on their concentration. In the second grade, they were mostly eager to teach the lesson in the accompaniment of classical music playing in the light background, but they were unsure that the music increased their concentration. This situation may show that second graders are more used to cadavers than first graders. While the first grade participated in the view that classical music must be in the anatomy laboratory, the rate of students who agree with this view was low. In this case, we can say that the second graders are used to seeing cadavers. In general, both first and second year students did not find it appropriate to use other music with lyrics instead of classical music. However, all classes showed a high degree of participation in the suggestion of using other non-verbal instrumental music instead of classical music. The following conclusion can be drawn here; students' interest in non-verbal instrumental music is more preferable than music with lyrics.

Students generally participated in the fact that the music played in the light background dissipated the cold gloom of the anatomy laboratory in the air of the morgue unit. In addition, participation in the view that music playing in the light background reduced fear and stress in approaching the cadaver, but provided better quality dissection, was quite high. Both first and second graders generally showed an indecisive attitude to the view that music playing in a light background reduced the rate of noise that might occur in the lesson, and the rate of those who disagreed with this view was quite high.

From the data obtained in this study, it can be said that the students liked to learn the anatomy practice lesson with classical 
Table 2. Frequencies (f) of answers given by the second year students to the questions Second year of the medicine faculty students $n=70$

1- I love to learn the anatomy practice lesson in company with classical music playing soft and lowpitched sounds in the background.

2- Learning and studying the anatomy practice lesson accompanied by classical music playing soft and low-pitched music increases my concentration.

3-While learning the anatomy practice lesson, there should be classical music playing a soft and low voice in the background.

4- While learning the anatomy practice lesson, other music with spoken can be used instead of classical music that plays soft and low sounds in the background.

5-Classical music playing soft and low sounds in the background during anatomy practice lessons can reduce fear and stress in encountering cadavers.

6- In anatomy practice lessons, if there is classical music playing a soft and low voice in the background, the noise that may occur during free study decreases, and thus, the concentration and understanding of the lesson increase.

7- In anatomy practice lessons, if there is a different style of music with lyrics instead of classical music that plays a soft and low voice in the background, the concentration and understanding of the lesson decreases and the lesson is not understood at all.

8- If the number of cadavers belonging to the anatomy department was large, performing a dissection accompanied by classical music playing a soft and low sound in the background would reduce fear and stress and enable students to learn the lesson better and be equipped.

9- Dissection accompanied by classical music playing a soft and low voice in the background in the classes where the students of the Faculty of Medicine receive anatomy lessons overcomes fear and stress, and provides adaptation to the first patient cadaver and prepares the ground for surgical lessons.

10- Classical music playing soft and low sounds in the background in anatomy practice lessons can soften the coldness and gloom of the laboratory, which is like a morgue unit, and reduce stress.

11- While learning the anatomy practice lesson, other non-verbal instrumental music can be used instead of classical music that plays soft and low-pitched sounds in the background.

\begin{tabular}{|c|c|c|c|c|}
\hline 5 & 4 & 3 & 2 & 1 \\
\hline 24.2 & 21.2 & 21.2 & 22.7 & 10.6 \\
\hline 19.7 & 19.7 & 27.3 & 10.6 & 22.7 \\
\hline 16.7 & 22.7 & 21.2 & 9.1 & 30.3 \\
\hline 6.2 & 20 & 12.3 & 34.4 & 26.2 \\
\hline 13.6 & 25.8 & 27.3 & 12.1 & 21.2 \\
\hline 15.2 & 24.2 & 22.7 & 13.6 & 24.2 \\
\hline 16.9 & 43.1 & 15.4 & 9.2 & 15.4 \\
\hline 19.7 & 42.4 & 12.1 & 9.1 & 16.7 \\
\hline 15.2 & 45.5 & 16.7 & 12.1 & 10.6 \\
\hline 15.2 & 50 & 7.6 & 9.1 & 18.2 \\
\hline 18.2 & 33.3 & 13.6 & 18.2 & 16.7 \\
\hline
\end{tabular}

5: Totally agree (\%), 4: Agree (\%), 3: Undecided (\%), 2: Totally disagree (\%), 1: Disagree (\%)

Table 3. P-values of first and second year students' answers to each question with chi-square test

\section{Questions}

1- I love to learn the anatomy practice lesson in company with classical music playing soft and low-pitched sounds in the background.

2- Learning and studying the anatomy practice lesson accompanied by classical music playing soft and lowpitched music increases my concentration.

3-While learning the anatomy practice lesson, there should be classical music playing a soft and low voice in the background.

4- While learning the anatomy practice lesson, other music with spoken can be used instead of classical music that plays soft and low sounds in the background.

5- Classical music playing soft and low sounds in the background during anatomy practice lessons can reduce fear and stress in encountering cadavers.

6-In anatomy practice lessons, if there is classical music playing a soft and low voice in the background, the noise that may occur during free study decreases, and thus, the concentration and understanding of the lesson increase.

7- In anatomy practice lessons, if there is a different style of music with lyrics instead of classical music that plays a soft and low voice in the background, the concentration and understanding of the lesson decreases and the lesson is not understood at all.

8- If the number of cadavers belonging to the anatomy department was large, performing a dissection accompanied by classical music playing a soft and low sound in the background would reduce fear and stress and enable students to learn the lesson better and be equipped.
Chi-square test of $1^{\text {st }}$ and $2^{\text {nd }}$ grade students $P$

0.017

0.057

0.032

0.015

0.244

0.961

0.090

0.558 


\begin{tabular}{|l|l|}
\hline \multicolumn{2}{|l|}{ Table 3 continued } \\
$\begin{array}{l}\text { 9- Dissection accompanied by classical music playing a soft and low voice in the background in the classes } \\
\text { where the students of the faculty of medicine receive anatomy lessons overcomes fear and stress, and provides } \\
\text { adaptation to the first patient cadaver and prepares the ground for surgical lessons. }\end{array}$ & 0.194 \\
\hline $\begin{array}{l}\text { 10- Classical music playing soft and low sounds in the background in anatomy practice lessons can soften the } \\
\text { coldness and gloom of the laboratory, which is like a morgue unit, and reduce stress. }\end{array}$ & 0.334 \\
\hline $\begin{array}{l}\text { 11- While learning the anatomy practice lesson, other non-verbal instrumental music can be used instead of } \\
\text { classical music that plays soft and low-pitched sounds in the background. }\end{array}$ & 0.073 \\
\hline
\end{tabular}

music playing in the light background. However, in the upper classes who are accustomed to seeing cadavers, participation in this situation is not too much. Because as you get used to seeing the cadaver, the stress and fear towards the cadaver decrease and the sense of anxiety awakened in the students is not much. All students have adopted that classical music playing on a light background increases the interest in the lesson, reduces stress and makes it easier to concentrate.

For anatomy practice lessons, light background classical music can be a recommended option for the interest and comfortable adaptation to the lessons. This study was a preliminary study for this option. Getting feedback from students also made a significant contribution to the educators.

\section{Study Limitations}

The study is limited with the answers of students who participated in the survey. The collected information was assumed to be true; the subjects involved in the study were assumed to give their answers honestly. The questionnaire was not a standardized instrument and could be validated in future studies.

\section{Conclusion}

For anatomy practice lessons, light background classical music can be an alternative for adaptation and learning to the lesson. There are very few studies on this in the literature. According to the data in the literature, students' approach to this type of education is quite positive. In this study, a preliminary study was conducted on student approaches to this education model in our country, and the approach and satisfaction of the students were positive.

\section{Acknowledgments}

Thanks to Sercan Kenan Başar and Bisher Tahhan, students of the Kafkas University Medical Faculty, who helped carry out this study.

\section{Ethics}

Ethics Committee Approval: The study was approved by the Ethics Committee of Kafkas University (approval number: 2020/06/ decision 11).

Informed Consent: Patient approval is not required as it is a survey study.

Peer-review: Externally peer-reviewed.
Financial Disclosure: The author declared that this study received no financial support.

\section{References}

1. Parker LM. Anatomical dissection: why are we cutting it out? Dissection in undergraduate teaching. ANZ J Surg. 2002;72:910-912. [Crossref]

2. Lewis TL, Burnett B, Tunstall RG, Abrahams PH. Complementing anatomy education using three-dimensional anatomy mobile software applications on tablet computers. Clin Anat. 2014;27:313-320. [Crossref]

3. Kotzé SH, Mole CG, Greyling LM. The translucent cadaver: An evaluation of the use of full body digital X-ray images and drawings in surface anatomy education. Anat Sci Educ. 2012;5:287-294. [Crossref]

4. Çetkin M, Turhan B, Bahşi I, Kervancıoğlu P. Tıp fakültesi öğrencilerinin anatomi eğitimi hakkındaki düşünceleri. Gaziantep Med J. 2016;22:82-88. [Crossref]

5. Older J. Anatomy: a must for teaching the next generation. Surgeon. 2004;2:79-90. [Crossref]

6. Singh R, Tubbs RS, Gupta K, Singh M, Jones DG, Kumar R. Is the decline of human anatomy hazardous to medical education/profession?-A review. Surg Radiol Anat. 2015;37:1257-1265. [Crossref]

7. McLachlan JC, Bligh J, Bradley P, Searle J. Teaching anatomy without cadavers. Med Educ. 2004;38:418-424. [Crossref]

8. McLachlan JC. New path for teaching anatomy: living anatomy and medical imaging vs. dissection. Anat Rec B New Anat. 2004;281:4-5. [Crossref]

9. Gupta J, Chaturvedi M, Patil M. Embalmed cadavers-Are they safe to handle, a study to see the microbial flora present in the embalmed cadavers. Int J Pharma Bio Sci. 2013;4;383-386. [Crossref]

10. Anyanwu GE, Nto JN, Agu AU, Ekezie J, Esom EA. Musical preferences and learning outcome of medical students in cadaver dissection laboratory: A Nigerian survey. Ann Anat. 2016;208:228-233. [Crossref]

11. Bellier A, Secheresse T, Stoeckle A, Dols AM, Chaffanjon PC. Impact of background music on medical student anxiety and performance during anatomical dissections: A cluster randomized interventional trial. Anat Sci Educ. 2020;13:427-435. [Crossref]

12. Anyanwu EG. Background music in the dissection laboratory: impact on stress associated with the dissection experience. Adv Physiol Educ. 2015;39:96-101. [Crossref]

13. Gözil R, Özkan S, Bahçelioğlu M, Kadıoğlu D, Çalgüner E, Öktem H, et al. Gazi Üniversitesi Tıp Fakültesi 2. Sınıf Öğrencilerinin Anatomi Eğitimini Değerlendirmeleri. Tıp Eğitimi Dünyası Derg. 2006;23:27-32. [Crossref]

14. Bahşi I, Topal Z, Çetkin M, Orhan M, Kervancıoğlu P, Odabaşıoğlu ME, et al. Evaluation of attitudes and opinions of medical faculty students against the use of cadaver in anatomy education and investigation of the factors affecting their emotional responses related thereto. Surg Radiol Anat. 2020:1-7. do.i: 10.1007/s00276-020-02567-8 [Crossref]

15. Estai M, Bunt S. Best teaching practices in anatomy education: A critical review. Ann Anat. 2016;208:151-157. [Crossref] 